dr Darko RADULOVIĆ, Docent ${ }^{*}$

Pravni fakultet,

Univerzitet Crne Gore
Pregledni naučni rad

UDK: 343.26

Primljeno:26.6.2020.

Prihvaćeno:15.7.2020.

https://doi.org/10.47152/rkkp.58.1.2.4

\title{
DUGOTRAJNI ILI DOŽIVOTNI ZATVOR
}

Sistem krivičnih sankcija je jedno od najznačajnijih pitanja krivičnog prava. To je i razumljivo imajuću u vidu da su krivične sankcije osnovno sredstvo za ostvarivanje zaštitne funkcije krivičnog prava. Zato svaka reformam, manje više uključuje i kivične sankcije. Autor u radu u uvodnim napomenama govori o značaju krivičnih sankcija uopšte, potom o kazni lišenja slobode koja je zauzela značajno mjesto u sistemu krivičnih sankcija. Iako je ona uvedena kao zamjena dotadašnjim surovim kaznama, njoj su upućivani i prigovori. Akcenat u ovom radu stavljen je na najteže kazne lišenja slobode - dugotrajni i doživotni zatvor u krivičnom zakonodavstvu država na prostoru bivše SFRJ. Izlaže se šta je zajedničko tim zakonodavstvima, a po čemu se razlikuju. Potom se izlaže kako je ovo pitanje regulisano u svakoj od država sa ovih prostora. Na kraju autor daje odgovor na pitanje postavljeno u naslovu ovog rada-dugotrajni ili doživotni zatvor.

Ključne reči: Zakon, teška krivična djela, dugotrajni zatvor, doživotni zatvor.

e-mail: darko77@t-com.me 


\section{O krivičnim sankcijama uopšte}

Krivične sankcije kao sredstvo reagovanja zakonodavca na kriminalitet zauzimaju značajno mjesto u krivičnim zakonima i mogli bismo reći, predstavljaju najdinamičniji dio krivičnog zakonodavstva. Njihov značaj i uloga koju njihova primjena ima u suzbijanju kriminaliteta zahtijevaju da one stalno budu usavršavane i prilagođavane društvenim potrebama u postojećim uslovima obima i strukture kriminalitteta u društvu (Đorđević, 2000:41). Zato skoro ni jedna reforma krivičnog zakonodavstva ne samo kod nas, nego i u uporednom zakonodavstvu, nije zaobišla sistem krivičnih sankcija. Tih reformi zadnje dvije decenije je bilo možda i previše. Skoro da se i ne naviknemo na primjenu krivičnog zakonodavstva (i materijalnog i procesnog), a ono se mijenja, pa se može postaviti i pitanje da li su nam potrebne tako česte reforme krivičnog zakonodavstva, posebno opšteg dijela. Izmjene posebnog dijela možemo opravdati činjenicom da se uvijek pojave neka antidruštvena ponašanja koja nisu pokrivena inkriminacijama. Ovo je prilika da se podsjetimo na misao profesora Radomira Lukića koji je davno napisao „da se treba čuvati suviše čestog mijenjanja normi, čak i kada je to opravdano, jer dugo trajanje normi ima svoju sopstvenu vrijednost koja ojačava njen autoritet i čini da se potpunije primjenjuje“ (Lukić, 1995:190). Razlozi za izmjene u ovoj oblasti su bili višestruki. To je, uglavnom, bilo uslovljeno, s jedne strane opštim društvenim razvojem i humanizacijom društvenog tretmana učinilaca krivičnih djela, a sa druge strane, praktičnim potrebama kriminalne politike da zavisno od stanja kriminaliteta u datom društvu i u određeno vrijeme kao i u skladu sa prihvaćenim principima na kojima se zasniva, reaguje određenim mjerama na društveno opasna ponašanja (Lazarević, 1987:30). U tom smislu razvojna linija sistema krivičnih sankcija odražava njegovo uklapanje u savremene kriminalno-političke procese kritičkim prihvatanjem pozitivnih tendencija i na tim osnovama ugrađivanje u zakonodavstvo novih rješenja, što znači da sistem krivičnih sankcija nije zatvoren za prodor novih ideja i osavremenjavanje sistema krivičnih sankcija, kako prihvatanjem ne samo onih koje su efikasnije u borbi protiv novih pojavnih oblika kriminaliteta, nego i onih humanijih. Ovaj dinamizam u razvoju sistema krivičnih sankcija i njegovo adaptiranje savremenim uslovima borbe protiv kriminaliteta odrazio se tako da su neke sankcije nastajale i još brže nestajale, neke su egzistirale duži ili kraći vremenski period, ali je jedna odoljela iskušenju vremena. Riječ je o kazni lišenja slobode, odnosno kazni zatvora.

U krivična zakonodavstva uvedena je krajem XVIII vijeka kao reakcija na svirepost i okrutnost represivnog sistema koji se do tada primjenjivao, u kojem su dominirale različite vrste tjelesnih kazni i smrtna kazna sa različitim oblicima izvršenja. Ona je veoma brzo stekla afirmaciju i postala, takoreći, univerzalno sredstvo kriminalne politike sa širokom primjenom u praksi. Međutim, istorija 
kazni lišenja slobode je istovremeno i istorija njenog osporavanja, jer su joj od samog početka njene primjene upućivani određeni prigovori. Prigovaralo se da je ova kazna sama po sebi predstavljala kriminogeni faktor jer se zbog skupnog izdržavanja kazne miješaju osuđenici za razna krivična djela, učinjena iz različitih motiva i pobuda, što može da doprinese tzv. „kriminalnoj zarazi“. Naglašavalo se da kod ovih kazni prevladava retributivni element, da one ne garantuju specijalnu prevenciju, a uz to, često se ističe da zatvor ne može da bude instrument readaptacije i osposobljavanja za društveni život učinioca krivičnog djela, jer je zatvor sam po sebi negacija društvenog života.

\section{O kazni dugotrajnog i doživotnog zatvora uopšte}

Kada je u pitanju kazna zatvora ili bolje rečeno kazna lišenja slobode (obzirom da ima, odnosno da je bilo više oblika zatvaranja) postavlja se nekoliko pitanja kao što su: pitanje njenog trajanja i vrsta kazni lišenja slobode. Kada je riječ o trajanju kazne zatvora posebnu pažnju ne samo stručne i naučne, nego i opšte javnosti zaokupljaju kratkotrajne kazne zatvora i sasvim na suprotnom kraju dugotrajne kazne zatvora. Ove prve su od samog uvođenja u krivično zakonodavstvo bile kamen spoticanja i sa kriminalnopolitičkog i sa penološkog stanovišta, pa se sve više u teoriji, a i u zakonodavstvu ide ka pronalaženju alternativa kratkotrajnim kaznama lišenja slobode (Radulović, 2009). Ništa manju pažnju nisu privlačile i dugotrajne kazne zatvora koje su na svojoj aktuelnosti posebno dobile onda kada je smrtna kazna koja je u većini zakonodavstava zadržana i nakon uvođenja kazne zatvora, izostavljena iz registra krivičnih sankcija, kada je postavljeno pitanje šta propisati za njenu alternativu, da li kaznu doživotnog ili dugotrajnog zatvora. To pitanje je i tema ovog rada. A rasprave o ovom problemu rekli bismo uvijek iznova počinju sa mnogobrojnim dilemama, a tako se i završavaju, mada sve ovo uslovno rečeno, jer ova tema koja je bila predmet razmatranja mnogih teoretičara, odnosno stručne javnosti, kao da nema kraja (Tomić, 2015:178).

Posmatrajući naše krivično zakonodavstvo u istorijskoj retrospektivi možemo naći da je kaznu doživotnog zatvora (robiju) poznavalo i krivično zakonodavstvo Kraljevine Jugoslavije, a u isto vrijeme za određena krivična djela bila je propisana i smrtna kazna. Prvi posljeratni Krivični zakonik iz 1948. godine u registru krivičnih sankcija predviđao je i kaznu lišenja slobode sa prinudnim radom koja je mogla biti vremenski ograničena i doživotna. Kaznu doživotnog zatvora sa prinudnim radom sud je mogao da izrekne za krivična djela za koja zakon propisuje smrtnu kaznu ako utvrdi da postoje objektivno-subjektivne okolnosti koje dopuštaju mogućnost ublažavanja kazne. Kazna doživotnog zatvora zadržana 
je i u Krivičnom zakoniku iz 1951. godine i bila je vezana za smrtnu kaznu, odnosno kao zamjena za smrtnu kaznu. Postojale su dvije mogućnosti izricanja ove kazne. Prva je kada sud ocijeni da smrtnu kaznu treba zamijeniti kaznom strogog zatvora u doživotnom trajanju, a druga mogućnost je da se aktom amnestije i pomilovanja, kao aktima milosti, smrtna kazna zamijeni kaznom strogog zatvora u doživotnom trajanju. Najviše pod uticajem ideja Nove društvene odbrane izmjenama Krivičnog zakonika iz 1959. godine kazna doživotnog zatvora brisana je iz registra krivičnih sankcija. Krivični zakon iz 1976. godine zadržao je smrtnu kaznu, kazna zatvora je unificirana sa opštim maksimumom petnaest godina ali je predviđena i kazna zatvora od dvadeset godina kao zamjena za smrtnu kaznu. Polazeći od Ustava SRJ iz 1992. godine (čl. 21 st. 2) gdje je bilo propisano da se smrtna kazna ne može predvidjeti za krivična djela koja se propisuju saveznim zakonom, u Krivičnom zakonu SRJ brisane su sve odredbe o toj kazni. To je dovelo, pomalo, do apsurda da se smrtna kazna ne može propisivati saveznim krivičnim zakonom, a može krivičnim zakonima republika (za teška ubistva i teške oblike razbojništva i razbojničke krađe) iako su u saveznoj nadležnosti ostala takođe teška krivična djela kao što su genocid, ratni zločin i slično (čitava grupa krivičnih djela protiv čovječnosti i drugih dobara zaštićenih međunarodnim pravom). Konačno je smrtna kazna ukinuta 2002. godine. Od tog momenta ostalo je otvoreno pitanje kojom kaznom popuniti mjesto koje je „ostalo prazno“ nakon brisanja smrtne kazne iz registra krivičnih sankcija. Već tada se upozoravalo da je tada smrtna kazna ukinuta u nepovoljnim opštim okolnostima, bez temeljnije procjene opravdanosti njenog daljeg zadržavanja u sistemu kazni, pa ta činjenica upućuje na oprez pri izboru njene zamjene (Subotić, 1996:116). Kao što se to radilo i ranije kod pripremanja nacrta krivičnih zakona, rješenje ovog pitanja moglo se naći u uporednom zakonodavstvu. Zamjenu za smrtnu kaznu uporedna zakonodavstva vide u kazni lišenja slobode, i to u dva vida - kazni doživotnog zatvora i kazni dugotrajnog zatvora. Prema navodima iz bogate dokumentacije u svojoj studiji iz 2019. godine Dirk van Zylsmit i Catherine Appleton može se vidjeti da od 216 država i teritorija njih 183 predviđaju mogućnost izricanja doživotne kazne zatvora (Ignjatović, 2019:122), dok 36 država nemaju u svom sistemu izričito propisanu kaznu doživotnog zatvora. U našoj literaturi je već tada bilo mišljenja da isključivanje kazne doživotnog zatvora na samom početku „stanja bez smrtne kazne“ bez ikakve iskustvene provjere njene djelotvornosti ne bi se moglo smatrati opravdanim (Subotić, 1996:116). Međutim, uzdržanost u ranijoj jugoslovenskoj krivičnoj teoriji prema kazni doživotnog zatvora najbolje je izražena kada je ona izmjenama Krivičnog zakonika iz 1959. g. brisana iz registra krivičnih sankcija (Petrić, 1999:341). U hrvatskoj krivičnoj teoriji svoje stanovište o kazni doživotnog zatvora slikovito je izrazio profesor Horvatić 
opaskom da je on „samo korak od antiabolicionizma i uvođenja smrtne kazne“ (Breneselović, 2011:333). I danas postoje mišljenja da ova kazna treba da bude izuzetna i da ona zamjenjuje smrtnu kaznu (Lazarević, Škulić, 2015:41; Stojanović, 2019:289). Drugi pak ističu da ovakvo stanovište ima vrednosni nedostatak jer se njime daje na značaju kazni koja je u najvećem dijelu svijeta ukinuta zbog svoje nehumanosti (Ilić, V. 2019:157).

Ne može se sporiti da doživotni zatvor koindicira sa ukidanjem smrtne kazne i sa ratifikacijom Protokola broj 6 uz Evropsku konvenciju o zaštiti ljudskih prava i osnovnih sloboda kojim je ukinuta smrtna kazna, što znači da je kroz istoriju bio povezan sa smrtnom kaznom. Iz tog razloga, zbog nehumanih karakteristika, mnogi za doživotni zatvor kažu da je „odložena smrtna kazna“ ili da predstavlja „civilnu smrt“ (Dimovski i drugi, 2019:96). Kaznu doživotnog zatvora najprostije možemo definisati kao kaznu kojom se odlukom suda osuđenom licu do kraja života oduzima sloboda (Ignjatović, 2019: 121), odnosno suspenduje sloboda kretanja na neodređeno vrijeme i smještanje osuđenika u posebnu zavodsku ustanovu (Dimovski i drugi, 2019:96).

Kad je riječ o kazni dugotrajnog zatvora ona se različito određuje u nauci i zakonodavstvu. Negdje se navodi da su to kazne lišenja slobode deset godina i više (Ignjatović, 2015:184), a negdje kazna zatvora od pet godina i više (Kambovski, 2006:666). Kad je riječ o zakonskom određenju ove kazne onda su to ekstremno duge kazne lišenja slobode izražena u fiksnom iznosu (na primjer 20, 30, 40 godina) ili u rasponu (na primjer od 20 do 30, od 20 do 40 godina) (Ćorović, 2018:196). Kao i za doživotni zatvor, tako se uzima i za dugotrajni zatvor da predstavlja zamjenu za smrtnu kaznu. Međutim, to ne bi trebao da bude i jedini razlog njihovog ozakonjenja. Zapravo, postavlja se pitanje da li legitimitet jedne kazne izvoditi iz nepostojanja i nelegitimiteta druge kazne, jer ako su ove kazne samo supstituti smrtnoj kazni, kako se ističe u literaturi, onda one nisu ništa drugo do puka retribucija, pa su zato upitne sa stanovišta načela humanosti, kao i sa stanovišta resocijalizacije koji se u savremenim zakonodavstvima proklamuju u vezi sa izricanjem i izvršenjem kazni, prije svega kazne zatvora (Ćorović, 2018:197).

\section{O kazni dugotrajnog i doživotnog zatvora u zemljama bivše SFRJ}

U zakonodavstvu zemalja na području bivše Jugoslavije (ili kako se to područje danas popularno naziva region) koje baštine krivično zakonodavstvo bivše nam zajedničke države ovo pitanje je različito uređeno, tako da imamo zastupljene i kaznu doživotnog i kaznu dugotrajnog zatvora, i jedna i druga su supstituti uki- 
nutoj smrtnoj kazni. Zajedničko im je to da se propisuju za najteža krivična djela, odnosno za teške oblike teških krivičnih djela i da se ne mogu propisati kao jedine nego uz „redovni“ zatvor. U nekim zakonodavstvima kazna dugotrajnijeg zatvora je bila, ili je propisana u fiksnom iznosu, a u drugim u rasponu.

Osim što su propisane za najteža krivična djela u zakonodavstvima postoje razlike u pogledu izuzimanja lica kojima se ne mogu izreći ove kazne. Ono što je još zajedničko ovim zakonodavstvima jeste tamo gdje je kazna doživotnog, odnosno dugotrajnog zatvora propisana za određena krivična djela, propisana je uz kaznu „redovnog“ zatvora najmanje deset godina (izuzev u KZ Hrvatske gdje je za neka krivična djela vezana za kaznu zatvora od pet godina, i u KZ Crne Gore gdje je za krivično djelo genocida vezana za kaznu zatvora najmanje osam godina, a u KZ Slovenije je vezana za kaznu zatvora najmanje petnaest godina).

Nakon prezentiranja zajedničkih karakteristika ovih kazni u krivičnom zakonodavstvu zemalja sa područja bivše Jugoslavije ukratko ćemo predstaviti zakonska rješenja ovih kazni u zakonodavstvima ovih zemalja.

1. Poznato je da u Bosni i Hercegovini imamo četiri krivična zakona/zakonika: Krivični zakon $\mathrm{BIH}^{1}$, Krivični zakon Federacije $\mathrm{BIH}^{2}$, Krivični zakonik Republike Srpske ${ }^{3}$ i Krivični zakon Brčko Distrikta ${ }^{4}$. Sva ova četiri zakona/zakonika predviđaju kaznu dugotrajnog zatvora. Potpuno su identična rješenja u krivičnim zakonima BIH, Federacije BIH i Brčko Distrikta tako da je kazna dugotrajnog zatvora propisana u rasponu od 21 do 45 godina, propisuje se za najteže oblike teških krivičnih djela i ne može se izreći licima koja u vrijeme izvršenja krivičnog djela nisu navršila 21 godinu. Nema nikakvih posebnih uslova za odobravanje uslovnog otpusta u odnosu na krivična djela za koja se izriče kazna zatvora.

Kazna dugotrajnog zatvora u krivičnom zakonodavstvu Republike Srpske prvobitno je bila propisana u Krivičnom zakoniku iz 2003. godine umjesto kazne doživotnog zatvora koja je bila predviđena u KZ iz 2000. godine, i to za najteže oblike teških krivičnih djela. Sada je ona propisana u novom KZ u članu 45 u rasponu od 25 do 45 godina i to za teška krivična djela i najteže oblike teških krivičnih djela. Dakle, ne samo za najteže oblike teških krivičnih djela (kao što je do sada bilo) nego i za najteža krivična djela čime se proširuje pravni okvir njene primjene. Isto kao u ostalim krivičnim/kaznenim zakonima u BIH ona se ne može izreći licima koja u vrijeme izvršenja krivičnog djela nisu navršila 21 godinu, ali se uz to dodaje da se ne može izreći trudnoj (bremenitoj) ženi. Ovo izu-

1 Službeni glasnik BIH br. 3/03, 54/04, 30/05, 53/06, 8/10, 47/14, 40/15 i 35/18

2 Službene novine br. 33/03, 21/04, 18/05, 42/10, 42/11, 59/14, 46/16, 75/17

3 Službeni glasnik br. 6/05, 21/10, 9/13

4 Službeni glasnik RS br. 64/17, 104/18. 
zimanje bremenitih žena od mogućnosti izricanja kazne dugotrajnog zatvora u literaturi je kritikovano i navodi se da je ono vjerovatno iz ranijeg zakonodavstva preuzeto po inerciji slijedeći rješenje kod ograničenja izricanja smrtne kazne. Uz to se naglašava da kazna dugotrajnog zatvora nema dodirnih tačaka sa smrtnom kaznom, a bliska je maksimalnoj kazni zatvora od dvadeset godina koja se može izreći i bremenitoj ženi, pa razlozi za ovo isključivanje nisu opravdani (Ikanović, 2019:13). Uslovni otpust, amnestija i pomilovanje mogu se dati tek nakon izdržane dvije trećine kazne dugotrajnog zatvora.

2. U Kaznenom zakonu Republike Hrvatske $e^{5}$ pored kazne zatvora postoji i kazna dugotrajnog zatvora (čl. 46) i to, možemo reći, izražena u dva oblika. Prvi oblik je izražen u rasponu od 21 do 40 godina. Drugi oblik je izražen u fiksnom iznosu pa je u članu 46 st. 2 propisano da se izuzetno za krivična djela počinjena u sticaju pod uslovima propisanim Kaznenim zakonom jedinstvena kazna dugotrajnog zatvora može izreći u trajanju od 50 godina. U odnosu na zakonodavstva u zemljama na prostoru bivše Jugoslavije postoji razlika kada je riječ o ograničenjima u odnosu na lica koja su izuzeta od primjene ove kazne. Tako se ova kazna ne može izreći licu koje u vrijeme izvršenja krivičnog djela nije navršilo osamnaest godina. Interesantno da je i ranije u literaturi bilo predloga da za mlađa punoljetna lica ne bi bilo opravdano uvoditi takvo ograničenje, jer u praksi ima slučajeva da ova lica vrše izuzetno teška krivična djela (Subotić, 1996:117).

Inače, bez obzira što kazna doživotnog zatvora predstavlja zamjenu za smrtnu kaznu pri rješavanju pitanja ograničenja u izricanju kazne doživotnog zatvora s obzirom na svojstva učinioca treba imati u vidu različite prirode doživotnog zatvora i smrtne kazne, jer dok ova druga znači fizičko uklanjanje učinioca, druga, pod određenim uslovima, može da bude korigovana putem uslovnog otpusta ili pomilovanja. Još da naglasimo da se u KZ Hrvatske ne naznačava da se dugotrajni zatvor može propisati za najteže oblike teških krivičnih djela, a isto tako ne postoje posebni uslovi za odobravanje uslovnog otpusta.

3. U Krivičnom zakoniku Sjeverne Makedonije ${ }^{6}$ u članu 33 gdje se navode vrste kazni pominje se samo kazna zatvora, a onda se u članu 35 st. 1 propisuje da kazna zatvora ne može da bude kraća od 30 dana, niti duža od dvadeset godina. Osim kazne zatvora u istom ovom članu pominje se kazna dugotrajnog i doživotnog zatvora. Zanimljivo je kako se pravnotehnički izražavaju ove kazne. Tako je kazna dugotrajnog zatvora određena u fiksnom iznosu od 40 godina, a može se izreći za krivična djela za koja je propisana i kazna doživotnog zatvora. U stavu 2 člana 35 se navodi ako je za krivično djelo izvršeno sa umišljajem

5 Narodne novine br. 125/11, 144/12, 56/15, 61/15, 101/17, 118/18 i 126/19

6 Službeni vesnik br. 82/13 i 132/14 
propisana kazna od 20 godina zatvora, za teške oblike tog krivičnog djela može da se propiše i kazna doživotnog zatvora. Ove kazne se ne mogu izreći licu koje u vrijeme izvršenja krivičnog djjela nije navršilo 21 godinu. Ako je neko lice osuđeno na kaznu doživotnog zatvora može se pustiti na uslovni otpust nakon 25 godina izdržane kazne.

4. Krivični zakon Slovenije ${ }^{7}$ poznaje kaznu doživotnog zatvora, ali je, slično kao u Krivičnom zakoniku Sjeverne Makedonije, posebno ne navodi u članu koji govori o vrstama kazni, nego je pominje u članu 46 koji reguliše kaznu zatvora. Tako je u članu 46 st. 1 propisan opšti minimum i maksimum kazne zatvora (od mjesec dana do 30 godina, a onda je u stavu 2 člana 46 predviđeno za koja se krivična djela može propisati kazna doživotnog zatvora. Tu se pominju krivična djela: genocid, zločin protiv čovječnosti, ratni zločin, agresija, terorizam, teško ubistvo, ubistvo predsjednika republike, ugrožavanje lica pod pratnjom ako dođe do smrti jednog ili više lica i krivično djelo uzimanja talaca ako dođe do nastupanja smrti jednog ili više lica. Kako vidimo, zanimljivo je da se u opštem dijelu Krivičnog zakonika navode krivična djela za koja se može propisati kazna doživotnog zatvora. Interesantno je i na koji način je u posebnom dijelu Krivičnog zakonika kod inkriminisanja naprijed navedenih krivičnih djela propisana kazna, gdje se ne pominje kazna doživotnog zatvora nego se propisuje da će se učinilac kazniti zatvorom najmanje petnaest godina. To ostavlja mogućnost sudu da primjenjujući opštu odredbu (čl. 46) učiniocem izrekne kaznu zatvora i do 30 godina ili kaznu doživotnog zatvora. Kazna doživotnog zatvora ne može se izreći licu koje u vrijeme izvršenja krivičnog djela nije navršilo 21 godinu. Uslovni otpust može se odobriti nakon izdržanih 25 godina kazne doživotnog zatvora.

5. U Krivičnom zakonodavstvu Srbije nakon što je 2002. godine smrtna kazna izbrisana iz sistema krivičnih sankcija tražila se zamjena toj kazni u odgovarajućem iznosu kazne zatvora. $U$ tom smislu te godine je kao zamjena za smrtnu kaznu uvedena kazna zatvora u fiksnom trajanju od 40 godina. Da li se ovdje radi o posebnoj vrsti kazne zatvora ili pak o posebnom opštem maksimumu kazne običnog zatvora mišljenja su podijeljena. Po jednima se radi o opštem maksimumu kazne zatvora (Lazarević, 2011:232), a drugi je tretiraju kao posebnu vrstu kazne zatvora (Stojanović, 2015(a):288; Đokić, 2016:225). Obzirom da je kazna „običnog“ zatvora propisana u rasponu od 30 dana do 20 godina i da se kazna zatvora ne može izricati od 20 do 40 godina razumljivo je da se kazna zatvora od 40 godina smatra posebnom vrstom kazne. Upravo radi ovolike vremenske distance između opšteg maksimuma kazne „običnog“ zatvora i kazne od 
40 godina zatvora Zakonom o izmjenama i dopunama Krivičnog zakonika ${ }^{8}$ učinjena je izmjena pa je dugotrajni zatvor umjesto u fiksnom iznosu od 40 godina preuređen pa je dat u rasponu od 30 do 40 godina, čime se smanjila razlika između opšteg maksimuma zatvora i donje granice dugotrajnog zatvora (Kolarić, 2016:205).

Međutim, s reformom krivičnog zakonodavstva u odnosu na kaznu koja će zamijeniti smrtnu kaznu tu se nije stalo pa je Zakonom o izmjenama i dopunama Krivičnog zakonika ${ }^{9}$ iz 2019. godine uvedena kazna doživotnog zatvora. Tako je u članu 44 st. 1 propisano: Da se za najteža krivična djela i za najteže oblike teških krivičnih djela može uz kaznu zatvora izuzetno propisati i kazna doživotnog zatvora. Propisano je (čl. 44 st. 2) koja su lica izuzeta od mogućnosti izricanja ove kazne, a to su lica koja u vrijeme izvršenja krivičnog djela nisu navršila 21 godinu života. Ovaj zatvor se ne može izreći ni u slučajevima kada zakon predviđa da se kazna može ublažiti ili kada postoji neki od osnova za oslobođenje od kazne. U obrazloženju Predloga Zakona stoji da kriminalno političko opravdanje doživotnog zatvora jeste $u$ tome što on treba da bude izuzetna mjera koja zamjenjuje smrtnu kaznu. Ovakvom obrazloženju se prigovara da nije u dobrom vremenskom kontekstu, te ako se uvodi u krivično zakonodavstvo kao zamjena za smrtnu kaznu, onda je to trebalo učiniti onda kada je smrtna kazna brisana iz sistema krivičnih sankcija (2002. g.), a ne skoro dvije decenije poslije (Ignjatović, 2019:124). Ako je tada ocijenjeno da je kazna od 40 godina adekvatna da zaštiti društvo od kriminaliteta, kada će takva lica i ako prežive okončanje tolike kazne doživjeti toliku starost, za koju kriminologija smatra da više biološki nisu sposobni za vršenje krivičnih djela, zašto onda sada uvoditi kaznu doživotnog zatvora.

U obrazloženju ozakonjenja ove kazne se poziva i na to da je u Evropi, pa i šire najzastupljenija (kao što smo već naveli poznaje je 183 zemlje, odnosno teritorije), kao i to da ona ima određeni simbolički značaj i da može da adekvatnije izrazi težinu nekih krivičnih djela i stepen krivice. Čak se ističe da se u izvršenju, faktički, može da svede i na kaznu zatvora od 40 godina (Stojanović, Kolarić, 2015:6). Takođe predlagači ističu i njen generalno preventivni značaj, što je opet u literaturi ocijenjeno kao nepoznavanje kriminoloških disciplina budući da se činioci koji navode ljude da vrše zločine ne nalaze u oblasti pravne regulative, a ideja o tome da kazna zatvora ima snažno generalno preventivno dejstvo, upravo kada su u pitanju ta djela za koja je propisana je odavno osporena u nauci (Ignjatović, 2019:126).

8 Službeni glasnik br. 85/05

9 Službeni glasnik br. 35/19 
Iako se kazni doživotnog zatvora prigovara da je nehumana, protagonisti ove kazne navode da u određenim slučajevima ona čak može da bude humanija od kazne dugotrajnog zatvora. Na primjer u slučaju kada osuđeni koji je izdržavao kaznu zatvora od 40 godina bude pred kraj svog života pušten na slobodu, time ništa ne dobija obzirom da je, po pravilu, bez sredstava za život, u dubokoj starosti, sa prekinutim vezama sa porodicom i prijateljima (Stojanović, Kolarić, 2015:7). Ima mišljenja da se kaznom doživotnog zatvora dobija jasnije razgraničenje sa kaznom zatvora, a izbjegava se arbitrarnost u pogledu njegovog trajanja jer trajanje doživotnog zatvora ne zavisi ni od zakonodavca ni suda (Kolarić, 2016:220).

Nakon predstavljanja ovih mišljenja ne smijemo zanemariti stav javnog mnjenja koje sa odobravanjem gleda na uvođenje doživotnog zatvora, jer dosadašnja iskustva govore da je naša javnost uvijek izražavala potrebu za represivnijim djelovanjem (Ćirić, 2014).

Uostalom, svima je poznato da je kazna doživotnog zatvora uvedena pod uticajem Fondacije „Tijana Jurić““. Uvođenje kazne doživotnog zatvora u krivično zakonodavstvo Srbije bilo je aktuelno i 2015. godine. O Nacrtu Izmjena i dopuna tog zakona izjašnjavao se i Vrhovni kasacioni sud i on se usprotivio tom predlogu i istakao ,,ako maksimalna kazna zatvora ostane zatvor od 20 godina, a uvede se doživotni zatvor kao najteža kazna, može se realno očekivati da će se sudovi teže opredjeljivati za doživotni zatvor, obzirom da je smanjena mogućnost da individualizaciju kazne, obzirom da između kazne zatvora od 20 godina i doživotnog zatvora sud nema mogućnosti da eventualno utvrdi, odnosno odmjeri kaznu zatvora koja će biti duža od 20 godina, ali ne takva da bude doživotni zatvor" (Bilten Vrhovnog kasacionog suda, 2015).

Iz naprijed predstavljenog vidimo da se u relativno kratkom vremenskom periodu često mijenjao stav zakonodavca u odnosu na iznalaženje adekvatne zamjene za smrtnu kaznu. Ono što je evidentno na te promjene je najmanje uticalo iskustvo u primjeni postojećih rješenja, jer se u kratkom vremenskom periodu nisu ni mogli sagledati efekti tih dugotrajnih kazni bilo da je ona bila izražena u fiksnom iznosu ili u odgovarajućem vremenskom razmaku. Zato nam se čini da je na ,raspoloženje“ zakonodavca ka uvođenju dugotrajnih kazni zatvora, pa i doživotnog veći uticaj bio spolja, od javnosti, nego li iz oblasti nauke i struke. Zato bi prilikom uvođenja kazne dugotrajnog odnosno doživotnog zatvora u krivično zakonodavstvo trebalo pristupiti racionalno, a ne emotivno, jer je kriminalna politika, kao i svaka politika racionalna djelatnost (Ćorović, 2018:208).

Ono što je karakteristično za kaznu doživotnog zatvora, kao, uostalom, i za smrtnu kaznu jeste da se ona ne odmjerava, nego se vrši samo njen izbor (Stojanović, 2015:6). Ili drugačije rečeno, izricanje kazne doživotnog zatvora se u poređenju sa drugim vrstama kazni odigrava u užem „slobodnom prostoru“, a 
to može uticati na realizaciju načela individualizacije kazne (Ilić,V. 2019:128). Imajući u vidu da se kod kazne doživotnog zatvora ne vrši odmjeravanje, nego izbor, a da je i dalje ostao opšti maksimum kazne zatvora 20 godina, mislimo da se u praksi neće „ostvariti očekivanja“ zakonodavstva o pooštravanju kaznene politike, jer će se sudovi upravo zbog velikog raspona između doživotnog zatvora i zatvora rjeđe opredjeljivati za kaznu doživotnog zatvora.

Kao što smo vidjeli naučna i stručna javnost je podijeljena u pogledu opravdanosti uvođenja u krivično zakonodavstvo kazne doživotnog zatvora. Međutim, ta ista javnost je nepodijeljena u osudi ograničenja mogućnosti odobravanja uslovnog otpusta za neka krivična djela za koja je propisana kazna doživotnog zatvora.

Tako je u članu 46 st. 5 isključena mogućnost da se osuđeni koji je osuđen na kaznu doživotnog zatvora pusti na uslovni otpust ako je izvršio krivično djelo: teško ubistvo (čl. 114 st. 1 tačka 9), silovanje (čl. 178 st. 4), obljuba nad nemoćnim licem (čl. 179 st. 3), obljuba sa djetetom (čl. 180 st. 3), obljuba zloupotrebom položaja (čl. 181 st. 5). U literaturi se navodi da se ne bi moglo reći da je samo težina krivičnog djela uticala na zakonodavca da zabrani uslovni otpust za ova krivična djela, jer ima podjednako teških, pa i težih krivičnih djela kod kojih nije isključena mogućnost uslovnog otpuštanja (Kolarić, 2019:26). U stvari, u obrazloženju Predloga zakona samo se kaže „u skladu sa inicijativom Fondacije „Tijana Jurić“ predviđeno je da sud ne može otpustiti osuđenog za krivična djela određena tom inicijativom (Dimovski, 2019:99). Zabrana uslovnog otpuštanja samo određene kategorije učinilaca, može se osporavati i sa aspekta ljudskih prava, odnosno nejednakom položaju građana pred zakonom. Može li se naći kriminalnopolitičko ili drugo objašnjenje zbog kojeg je, primjera radi, zabranjeno uslovno otpuštanje učinioca ubistva djeteta, a dozvoljeno otpuštanje osuđenog za genocid, ratni zločin ili zločin protiv čovječnosti (Ilić V., 2019:157). U svakom slučaju, nije dovoljno objašnjenje da je razlog uskraćivanja uslovnog otpusta to što se radi o nečijoj inicijativi. Još da dodamo da je i za ona krivična djela koja nisu izuzeta od mogućnosti uslovnog otpuštanja, propisano da osuđeni na kaznu doživotnog zatvora mora da izdrži najmanje 27 godina da bi mogao da se pusti na uslovni otpust što je suprotno stavu Evropskog suda za ljudska prava po kome osuđeni na kaznu doživotnog zatvora ima pravo na preispitivanje potrebe daljeg izdržavanja doživotnog zatvora poslije 25 godina. Imajući u vidu da se kod izricanja kazne doživotnog zatvora ne vrši odmjeravanje, nego izbor kazne, bez sumnje uslovni otpust predstavlja ključni mehanizam uz pomoć kojeg se nadomješćuje nedostajuće odmjeravanje kazne, jer se na osnovu ocjene prije svega ličnih crta osuđenog, a ne težine krivičnog djela, određuje stvarno trajanje kazne doživotnog zatvora (Stojanović, 2015:6; Ignjatović, 2016:54; Ilić G., 2019:128). 
Da li je uvođenje kazne doživotnog zatvora iniciralo i dopunu člana 42 novom tačkom 4 u kojoj se navodi da je svrha kažnjavanja „ostvarivanje pravednosti i srazmjernosti između učinjenog djela i težine krivične sankcije" u literaturi je različito komentarisano. Po jednom mišljenju upravo je kazna doživotnog zatvora ograničena principom pravednosti i srazmjernosti (Stojanović, 2015:7). Po drugom mišljenju ovo normativno proširenje svrhe kažnjavanja ne bi trebalo dovoditi u vezu isključivo sa kaznom doživotnog zatvora, ali je nesumnjiv retributivni naboj novog cilja, te samim tim i veza koja postoji i sa kaznom doživotnog zatvora, a pravednost i srazmjernost predstavljaju svojevrsno retributivno mjerilo kroz koje se posmatra težina krivičnog djela i odlučuje o kazni, pa i o kazni doživotnog zatvora (Ilić G., 2019:127). Imamo i one koji jasno kažu da se radi o pokušaju ,prilagođavanja“ odredaba o svrsi kažnjavanja doživotnom zatvoru bez mogućnosti uslovnog otpusta, stavljanjem akcenta na retribuciju odjevenu u ,fino ruho" pravednosti i srazmjernosti (Ilić V., 2019:158).

Mislimo da nije bilo nikakve potrebe za ovom novom tačkom o svrsi kažnjavanja, bez obzira na uvođenje kazne doživotnog zatvora u registar kazni jer prilikom odmjeravanja bilo koje kazne, između ostalog, mora se imati u vidu i pravednost i srazmjernost između učinjenog krivičnog djela i težine kazne.

Ustav Srbije u članu 20 st. 2 propisuje posebnu zaštitu sloboda i prava građana gdje se kaže da se dostignuti nivo ljudskih i manjinskih prava ne može smanjiti, pa ima mišljenja da je uvođenjem doživotnog zatvora bez mogućnosti uslovnog otpusta povrijeđen osnovni i najviši pravni akt (Dimovski i drugi, 2019:97).

Postavlja se pitanje da li je uvođenje kazne doživotnog zatvora u suprotnosti sa članom 3 Evropske konvencije o zaštiti ljudskih prava i osnovnih sloboda. O tome se više puta izjašnjavao Evropski sud za ljudska prava a najčešće se pominje stanovište Velikog vijeća iskazano u presudi Vinter i ostali protiv Ujedinjenog Kraljevstva (Odluka od 9. jula 2013. g., po predstavci 66069/09, 130/10 i 3896/10 par. 103-122), gdje se ne dovodi u pitanje postojanje kazne doživotnog zatvora, ali je nužno da je nacionalnim zakonodavstvom predviđen mehanizam koji predviđa mogućnost da nadležni organ nakon određenog vremena, a ne duže od 25 godina od početka izdržavanja ispita da li su kod osuđenog nastupile tako značajne promjene i da je postignut takav napredak ka rehabilitaciji da nastavak izdržavanja te kazne ne bi bio opravdan penološkim razlozima. Ono što je bitno jeste da ova mogućnost osuđenom mora da bude poznata još u toku trajanja krivičnog postupka. U suprotnom, ako domaće pravo ne obezbjeđuje nijedan mehanizam ili mogućnost preispitivanja kazne doživotnog zatvora, neusaglašenost te kazne sa članom 3 EKLJP po ovom osnovu se pojavljuje već u trenutku njenog izricanja, a ne u trenutku njenog izdržavanja (Ilić G., 2019:130). 
Podsjećamo da i Rimski statut kojim je osnovan stalni Međunarodni krivični sud predviđa mogućnost izricanja kazne doživotnog zatvora pod uslovom da je to opravdano ekstremnom težinom zločina i individualnim okolnostima vezanim za ličnost učinioca. Ima mišljenja da ova odredba Statuta posredno obavezuje nacionalna zakonodavstva (Kolarić, 2016:220). Međutim, ako pogledamo član 80 Statuta onda ćemo vidjeti da on iziričito naglašava da ništa u ovom dijelu Statuta (dio sedmi koji je posvećen kaznama) ne utiče na primjenu kazni od strane države, koje određuje pravni sistem te države, kao i zakon država koje ne primjenjuju kazne opisane u ovom dijelu. Prema tome, ne može se smatrati da propisivanje kazne doživotnog zatvora predstavlja ispunjenje međunarodne obaveze u smislu usklađivanja nacionalnog zakonodavstva sa navedenim Statutom (Ćorović, 2015:84).

6. Nakon brisanja smrtne kazne iz registra krivičnih sankcija zakonodavac u Crnoj Gori se, poput drugih država sa prostora bivše Jugoslavije, našao pred izazovom koju kaznu predvidjeti kao zamjenu za smrtnu kaznu. Opredijelio se za kaznu zatvora od trideset godina i to je tada bilo u odnosu na ostale države iz okruženja najblaža kazna, ali se smatralo da je to adekvatna zamjena za smrtnu kaznu. U tom smislu u članu 35 Krivičnog zakonika ${ }^{10}$ je propisano da se: za najteže oblike teških krivičnih djela može propisati kazna zatvora od trideset godina, s tim da se ne može propisati kao jedina kazna za određeno krivično djelo. U stavu 2 člana 35 propisano je da se ona ne može izreći: a) licu koje u vrijeme izvršenja krivičnog djela nije navršilo dvadeset jednu godinu života, b) licu kojem je u vrijeme izvršenja krivičnog djela uračunljivost bila bitno smanjena, c) za pokušaj krivičnog djela. Iz citiranih odredbi može se zaključiti da je prvi uslov da se radi o ,najtežem obliku teškog krivičnog djela“, a to znači da se radi o djelu koje se u osnovnom obliku ne može smatrati ,najtežim“ već takvim postaje nastupanjem neke posebno otežavajuće okolnosti (Lazarević i drugi, 2004:111). Međutim, ako se pogleda posebni dio Krivičnog zakonika onda se može primijetiti da zakonodavac nije ostao dosledan članu 35 st. 1 budući da je taj zatvor propisao i za neka krivična djela koja nemaju teže oblike, kao što je na primjer genocid, zločin protiv čovječnosti i slično.

Bilo je primjedbi zašto nisu izuzeta od primjene ove kazne još neka lica kao što su bremenite žene, lica u poodmakloj starosnoj dobi, žene koje imaju maloljetnu djecu i slično (Lazarević i drugi, 2010:116).

Tako česte izmjene našeg zakonodavstva nisu zaobišle ni kaznu zatvora. Ubrzo, nakon tri godine od donošenja Krivičnog zakonika uslijedile su njegove izmjene i dopune donošenjem Zakona o izmjenama i dopunama Krivičnog za-

10 Službeni list RCG br. 70/03 
konika ${ }^{11}$ 2006. godine kojim je kazna od trideset godina zamijenjena kaznom od četrdeset godina zatvora. Šta je bio ratio legis ove izmjene nije sasvim jasno ako se za tako kratko vrijeme nije moglo ni sagledati kriminalno političko opravdanje dotadašnje kazne imajući u vidu da je u tom periodu u vrlo malo slučajeva i izricana. Možda je jedan od razloga bio i to što u odnosu na zakonodavstva u okruženju je bio i najniža kazna, a predstavljala je zamjenu za smrtnu kaznu. Svakako razlog nije u činjenici što za period od trideset godina nije moguća potpuna resocijalizacija, pa bismo mogli reći da su za ovu promjenu primarni razlozi generalne prevencije. Inače, vlada mišljenje da svako lišenje slobode koje traje preko deset godina progresivno dovodi do uništavanja ličnosti osuđenog, a prelomnim se smatraju dvanaest ili petnaest godina neprekidnog boravka u zatvoru kada se kod zatvorenika pojavljuju stadijumi rezignacije, depresije i ravnodušnosti (Đorđević Đ., 2002:88). Zašto se zakonodavac opredijelio za četrdeset godina (tada je u KZ Srbije takođe bila u fiksnom iznosu od 40 godina isto kao u Makedoniji, a u KZ Hrvatske kao gornja granica dugotrajnog zatvora) i kako pravdati činjenicu da se zatvor ne smije odmjeravati između opšteg maksimuma (dvadeset godina) i te kazne? Vjerovatno se radi o kriminalno-političkoj procjeni koja teško može da se temelji na nekim objektivnim kriterijumima, pa se u literaturi ocjenjuje da je opredjeljivanje za najtežu kaznu istovremeno dobar primjer da je stvaranje krivičnog prava i subjektivan čin (Stojanović, 2005:17). I dalje je ostalo da se kazna zatvora od 40 godina može propisati za najteže oblike teških krivičnih djela i pored toga što je u posebnom dijelu, kao što smo već naglasili, propisan i za neka krivična djela koja nemaju teške oblike. Zakonodavcu je trebalo sedam godina da uoči tu nedosljednost pa je Zakonom o izmjenama i dopunama Krivičnog zakonika ${ }^{12}$ iz 2010. godine otklonio tu protivrječnost time što je u članu 35 st. 1 riječi „,najteže oblike teških krivičnih djela“ zamijenio riječima „,najteža krivična djela“.

Iako je povećanjem fiksnog iznosa kazne zatvora sa 30 godina na 40 godina zatvora, gledano sa legislativnog aspekta, pooštrena kaznena politika mislimo da to u praktičnom pogledu neće imati značajnijeg uticaja. I dok je ta kazna bila 30 godina, pa i nakon toga 40 godina osnovni problem je što se nije u onim slučajevima kada su izricane te kazne vršilo odmjeravanje kazne nego izbor kazne. Zbog velike razlike između opšteg maksimuma kazne „običnog“ zatvora i ove najteže izražene u fiksnom iznosu ima slučajeva da je teško nekom učiniocu ili pak saučesniku izreći ovu najstrožu kaznu, a i opšti maksimum kazne zatvora. To će u praksi uticati da će se sudovi radije odlučivati za opšti maksimum kazne „običnog“ zatvora, nego

11 Službeni list RCG br. 47/06

12 Službeni list CG br. 25/10 
za najstrožu kaznu. Inače, često se kaže da nam je zakonska kaznena politika stroga, a sudska kaznena politika blaga. Zato je bolje rješenje kojeg imamo u zemljama iz okruženja da se kazna dugotrajnog zatvora propisuje u rasponu, nego u fiksnom iznosu. Nakon eksperimentisanja sa fiksnim iznosom najstrože kazne zatvora u našem zakonodavstvu, zakonodavac se konačno priklonio onim zakonodavstvima koja zamjenu za smrtnu kaznu nalaze u kazni dugotrajnog zatvora, pa je Zakonom o izmjenama i dopunama Krivičnog zakonika ${ }^{13}$ iz 2017. godine i nominalno uveo kaznu dugotrajnog zatvora i odredio je u rasponu od 30 do 40 godina. Obrazloženje ove izmjene dato je samo u jednoj rečenici pa se kaže: „Predložena izmjena je potreba prakse naročito u slučajevima kada su izvršena najteža krivična djela od strane saizvršilaca, a u odnosu na jednog saizvršioca postoje dvije ili više naročito olakšavajućih okolnosti.“ Postavlja se pitanje da li je postojeće rješenje (misli se na rješenje kada je ova kazna bila u fiksnom iznosu od 40 godina) adekvatno u ovim slučajevima, tj. da se tom saizvršiocu može izreći kazna zatvora od 20 godina ili kazna zatvora od 40 godina. Ako se vratimo unazad i pogledamo kako je bilo zakonsko uređenje ove najstrože kazne vidimo da je ovdje za minimum kazne dugotrajnog zatvora uzeta ona u fiksnom iznosu iz 2003. godine a maksimum (40 godina) ona koja je uvedena Novelom KZ iz 2006. godine. Ovom novelom KZ i uvođenjem kazne dugotrajnog zatvora u rasponu, a ne u fiksnom iznosu, učinjen je izvjesni napredak ka individualizaciji ove kazne (a ne samo izboru što je bilo prije toga), ali problemi su samo ublaženi, ali nijesu riješeni. Po našem mišljenju i dalje je ostala velika diskrepanca između opšteg maksimuma zatvora i posebnog minimuma kazne dugotrajnog zatvora. Mislimo da je bolje rješenje koje je prihvaćeno u KZ Hrvatske (od 21 do 40 godina) ili u Krivičnim zakonima u BIH (od 21 do 45, odnosno u Republici Srpskoj od 25 do 45 g.). Raspon od deset godina koji razdvaja ova dva modaliteta kazne zatvora mislimo da je dugačak. Ako su ispunjeni uslovi za strogo kažnjavanje sudu se ostavlja mogućnost ili maksimum kazne zatvora od 20 godina ili zatvor između 30 i 40 godina (dugotrajni zatvor). Šta ako se sudu čini da je dvadeset godina malo, a trideset puno?

\section{Zaključak}

Na kraju kako da odgovorimo na pitanje postavljeno u naslovu ovog rada dugotrajni ili doživotni zatvor? Ako imamo u vidu rešenja u uporednom zakonodavstvu onda možemo zapaziti da oko $85 \%$ država i posebnih teritorija u svijetu poznaje kaznu doživotnog zatvora, a tek ostatak kaznu dugotrajnog zatvora. Mi-

13 Službeni list CG br. 44/17 
slimo ako bi se, same za sebe posmatrale ove dvije kazne bez uključivanja drugih instituta krivičnog prava, onda ne bi bilo razlike, ili bi ona bila vrlo mala između ovih kazni imajući u vidu da će za mnoge učinioce i kazna dugotrajnog zatvora biti doživotni zatvor. Od tih drugih instituta svakako je na prvom mjestu uslovni otpust kojeg bi trebalo da ima i osuđeni na dugotrajni i osuđeni na doživotni zatvor. Ovaj drugi pod drugačijim uslovima, uključujući i izdržanih ne više od 25 godina. Ta smanjivost kazne treba da bude rezultat njegovog ponašanja. I jedan i drugi zatvor imaju naglašen retributivno-represivni karakter, s tim što ne treba zanemariti ni mogućnost resocijalizacije, u koju kod učinilaca teških krivičnih djela puno ne vjerujemo. Ali, mi moramo priznati ljudsko dostojanstvo i prema učiniocima teških krivičnih djela iako ga oni često nisu spremni da priznaju drugima prvenstveno onim protiv kojih su učinili tako teška krivična djela. Ljudsko dostojanstvo je zato esencija koja razlikuje državu od osuđenog, kap koju može da upije površna zatvorenička svakodnevica, ali može da bude i presudni činilac koji će pripomoći klijanju nade da je preobražaj moguć (Ilić G., 2019:140).

Ako se opredijelimo za kaznu dugotrajnog zatvora bolje je da ona bude predviđena u određenom rasponu čija će donja granica biti bliža maksimalnoj kazni običnog zatvora, jer je u našem zakonodavstvu ta diskrapanca i nakon prelaska ove kazne izražene u fiksnom iznosu na njeno određenje u rasponu i dalje velika. Kod pooštravanja kaznene politike (uvođenjem strogih kazni) ne treba izgubiti iz vida da i nauka i praksa odavno ukazuju da povećanje represije ne vodi suzbijanju teških oblika kriminaliteta, a nerijetko na pooštravanje kaznene politike utiče i laička javnost ponukana pojedinačnim slučajevima teških krivičnih djela, pa su nekada i zakoni simbolički nazivani imenima žrtava krivičnih djela. Uostalom, davno je rekao Bekarija da je bolje da kažnjavanje bude brzo i izvjesno, nego da bude oštro jer se samo na taj način postiže efikasnost.

\section{Literatura}

- Breneselović, L. (2011) Kazna doživotnog lišenja slobode prema njemačkom Krivičnom zakoniku, u Uvod u pravo Njemačke. Beograd: Institut za uporedno pravo i Pravni fakultet u Beogradu.

- Ćirić, J. (2014) Pravosuđe i pritisci javnosti. U: Reformama krivičnog prava. Kopaonik: Udruženje javnih tužilaca i zamjenika javnih tužilaca Srbije.

- Ćorović, E. (2015) Sistem krivičnih sankcija Republike Srbije. SVEN: Novi Pazar.

- Ćorović, E. (2018) Kazna doživotnog zatvora (da ili ne). U: Organizacija pravosuđa i efikasnost sudske zaštite (Evropski standardi i stanje u Srbiji - krivičnopravni aspekt). Zlatibor: Srpsko udruženje za krivičnopravnu teoriju i prasku. 
- Dimovski, D., Vujačić, M., Jovanović, M. (2019) Doživotna kazna zatvora zakonodavstvo Srbije i međunarodni standardi. Pravna riječ, 60.

- Đokić, I. (2016) Reforma kazne zatvora u krivičnom zakonodavstvu Republike Srbije - kazna zatvora u dugom trajanju ili doživotni zatvor. U: Evropske integracije i kazneno zakonodavstvo (Poglavlje 23 - norma, praksa i mere harmonizacije). Zlatibor: Srpsko udruženje za krivičnopravnu teoriju i prasku.

- Đorđević, Đ. (2002) Kazna zatvora u Krivičnom zakoniku SRJ posle njegovih najnovijih izmena. U: Mesto jugoslovenskog krivičnog prava u savremenom krivičnom pravu. Beograd: Srpsko udruženje za krivično pravo.

- Đorđević, M. (2000) Krivične sankcije prema najnovijim rešenjima u Nacrtu Krivičnog zakonika. U: Reforma sistema izvršenja krivičnih sankcija. Beograd: Udruženje za penologiju Jugoslavije.

- Ignjatović, Đ. (2019) Kazna doživotnog zatvora - razlozi uvođenja i osvrt na rešenja u poslednjoj Noveli Krivičnog zakonika. U: Izmjene u krivičnom zakonodavstvu i status nosilaca pravosudnih funkcija i adekvatnost državne reakcije na kriminalitet (međunarodni pravni standardi i stanje u Srbiji). Zlatibor: Srpsko udruženje za krivičnopravnu teoriju i prasku.

- Ignjatović, Đ. (2015) Kriminologija. Beograd: Pravni fakultet Univerziteta u Beogradu.

- Ignjatović, Đ. (2016) Uslovni otpust - pravno i penološka analiza. Anali Pravnog fakulteta u Beogradu, 1, str. 31-66.

- Ikanović, V. (2019) Sistem kazni u Krivičnom zakoniku Republike Srpske. U: Kaznena politika i prevencija kriminaliteta. Trebinje: Srpsko udruženje za krivičnopravnu teoriju i prasku.

- Ilić, G. (2019) Marginalije o kazni doživotnog zatvora, uslovnom otpustu i ljudskim pravima. U: Đ. Ignjatović (ur.) Kaznena reakcija u Srbiji IX deo. Beograd: Pravni fakultet, Univerzitet u Beogradu, str. 123-142.

- Ilić, V. (2019) (Ne)pomirljivost kazne doživotnog zatvora i ljudskih prava. Crimen, 10(2), str. 156-173.

- Kambovski, V. (2006) Kazneno pravo, Opšt del. Štip - Skopje: Praven Fakultet ,Justinijan“.

- Kolarić, D. (2016) Reforma sistema kazni u funkciji suzbijanja kriminaliteta, RKK, 54(2-3), str. 203-236.

- Kolarić, D. (2019) Krivični zakonik i (ne)adekvatnost državne reakcije na kriminalitet (sadašnje stanje i nova rešenja). U: Izmene u krivičnom zakonodavstvu i statusu nosilaca pravosudnih funkcija i adekvatnost državne reakcije na kriminalitet. Zlatibor: Srpsko udruženje za krivičnopravnu teoriju i prasku.

- Lazarević, Lj. (1987) Sistem krivičnih sankcija. JRKK, 25(2), str. 28-45. 
- Lazarević, Lj., Vučković, B., Vučković, V. (2004) Komentar Krivičnog zakonika Crne Gore. Cetinje: Obod.

- Lazarević, Lj., Vučković, B., Vučković, V. (2010) Komentar Krivičnog zakonika Crne Gore. Tivat: Fakultet za mediteranske poslovne studije.

- Lazarević, Lj. (2011) Komentar Krivičnog zakonika Srbije. Beograd: Savremena administracija.

- Lazarević, J., Škulić, M. (2015) Osnovne planirane novele Krivičnog zakonika Srbije. Bilten Vrhovnog Kasacionog suda Srbije, 2.

- Lukić, R. (1995) Metodologija prava. Beograd: BIGZ.

- Petrić, B. (1999) Smrtna kazna: da ili ne. Glasnik AKV, 71(10), str. 336-351.

- Radulović, D. (2009) Alternative kratkotrajnoj kazni zatvora. Podgorica: Pravni fakultet u Podgorici.

- Stojanović, Z. (2015) Sistem kazni u krivičnom pravu Srbije i potreba njegovog daljeg usavršavanja. U: Đ. Ignjatović (ur.) Kaznena reakcija u Srbiji, V deo. Beograd: Pravni fakultet Univerziteta u Beogradu, str. 1-24.

- Stojanović, Z. (2015a) Krivično pravo, Opšti deo. Beograd: Pravni fakultet Univerziteta u Beogradu.

- Stojanović, Z. (2019) Krivično pravo, Opšti deo. Beograd: Pravni fakultet Univerziteta u Beogradu.

- Stojanović ,Z. (2005) Pravno filozofske koncepcije u Predlogu Krivičnog zakonika Srbije, u Krivičnom zakoniku Crne Gore. U: Kazneno zakonodavstvo progresivna ili regresivna rešenja. Beograd : Institut za kriminološka i socialna istraživanja.

- Stojanović, Z., Kolarić, D. (2015) U susret Zakonu o izmjenama i dopunama Krivičnog zakonika. U: Suprotstavljanje savremenim oblicima kriminaliteta analiza stanja, evropski standardi $i$ mere za unapređenje. Tara: Kriminalističko-policijska akademija.

- Subotić, D. (1996) Kazna lišenja slobode sa posebnim osvrtom na ukidanje smrtne kazne, JRKK, 34(3), str. 113-122.

- Tomić, M. (2015) Kazna doživotnog zatvora. U: Suđenje u razumnom roku $i$ drugi krivičnopravni instrumenti adekvatne državne reakcije na kriminalitet. Zlatibor: Srpsko udruženje za krivičnopravnu teoriju i prasku. 


\section{Darko RADULOVIĆ, PhD \\ Faculty of Law, University of Montenegro}

\section{LONG-TERM OR LIFE IMPRISONMENT}

The system of criminal sanctions is one of the most important issues in criminal law. This is understandable, bearing in mind that criminal sanctions represent the basic tool for implementing the protective function of criminal law. Consequently, every reform more or less includes criminal sanctions as well. In the introductory remarks of the paper, the author writes about the significance of criminal sanctions in general, and then about the sanction of detention which has taken an important position in the criminal sanctions system. Even though it was introduced to replace the previous severe punishments, it also received some complaints. The focus of this work is on the most severe forms of detention-long-term and life imprisonment, in the criminal legislation of the former Yugoslav countries. The author expresses the similarities and the differences between these legislations. This is followed by an overview of how this matter has been regulated in each of the countries from the region. Ultimately, the author provides a response to the question asked in the title of this paper-long-term or life imprisonment.

Key words: Law, serious criminal offences, long-term imprisonment, life imprisonment. 